\title{
FTIR-PCFC coupling: A new method for studying the combustion of polymers
}

\author{
Rodolphe Sonnier ${ }^{\mathrm{a}, *}$, Gaëlle Dorez ${ }^{\mathrm{a}}$, Henri Vahabi ${ }^{\mathrm{b}}$, Claire Longuet ${ }^{\mathrm{a}}$, Laurent Ferry ${ }^{\mathrm{a}}$ \\ ${ }^{a}$ C2MA, Ecole des Mines d'Alès, 30100 Alès, France \\ ${ }^{\mathrm{b}}$ Université de Lorraine, Laboratoire MOPS E.A. 4423, Metz F-57070, France
}

\begin{abstract}
A B S T R A C T
Gases released from pyrolysis and partial combustion of various polymers (low-density polyethylene, polystyrene, poly(parabromostyrene), pure and flame-retarded polypolyamide 6, cellulose, and chloroprene) were studied using a new coupling between Fourier transform infrared spectrometry (FTIR) and pyrolysis combustion flow calorimetry (PCFC). Combustion in PCFC was monitored by modifying the combustion temperature between 600 and $900{ }^{\circ} \mathrm{C}$. Decreasing the combustion temperature in PCFC leads to partial combustion and the evolution of $\mathrm{CO}$, but also of methane, acetylene, or ethylene when temperature is very low. The evolution of these gases depends also on the polymer and on the presence of a flame inhibitor, demonstrating that flame inhibition can be studied using this method. A correlation between FTIR-PCFC and FTIR-cone calorimetry coupling was attempted via the $\mathrm{CO} / \mathrm{CO}_{2}$ ratio. The first results show that an "isoconversion temperature" in the cone calorimeter test may be estimated. Polar gases such as chlorinated or brominated gases are not fully observed using this method due to possible adsorption in the transfer line before they reach the FTIR gas cell.
\end{abstract}

Keywords:

Pyrolysis combustion flow calorimetry

Fourier transform infrared spectroscopy

Combustion efficiency

Flame inhibition

\section{Introduction}

When exposed to an intense source of heat, a polymeric material undergoes heating up to a temperature high enough to break covalent bonds, leading to pyrolysis. The release of combustible gases increases until combustion starts. Combustion can be complete or partial, depending on the temperature, the excess of oxygen, the nature of combustible gases, and the presence of flame inhibitors (generally halogenated compounds). The completeness of combustion can be estimated by the ratio between the effective heat of combustion (EHC) and the heat of complete combustion. This ratio is called combustion efficiency $(\chi)$. Effective heat of combustion (respectively heat of complete combustion) is defined as the heat of the oxidation (respectively complete oxidation) of gases released from the anaerobic pyrolysis of a polymeric material.

The more complete the combustion, the higher is the heat release. This heat release adds to the initial source of heat, entailing an increase of the pyrolysis rate. Combustion efficiency is monitored by several parameters that can slow down the combustion kinetics without modifying the equilibrium yields of reactions. Therefore, to predict the pyrolysis rate, it is necessary to know how the combustion efficiency changes with the temperature of combustion, the oxygen rate, and the presence of flame inhibitors.

\footnotetext{
* Corresponding author.

E-mail address: rodolphe.sonnier@mines-ales.fr (R. Sonnier).
}

A new technique has recently been developed for studying the combustion efficiency of polymers using pyrolysis combustion flow calorimetry (PCFC) [1]. PCFC was developed by Lyon from FAA and allows measuring the flammability of small samples (2-5 mg) [2]. The sample is heated under nitrogen flow at $1 \mathrm{~K} / \mathrm{s}$, typically up to $750{ }^{\circ} \mathrm{C}$. The pyrolysis gases are sent to a tube furnace, where combustion occurs. Therefore, combustion and pyrolysis are well separated and the temperature and the oxygen rate can be monitored. The heat release is measured using an oxygen analyzer. According to the Huggett relation [3], $1 \mathrm{~kg}$ of oxygen consumed during the combustion corresponds to $13.1 \mathrm{MJ}$ of released energy. Hence, it is possible to measure the combustion efficiency under well-controlled conditions. In recent papers, it was shown that the curve of combustion efficiency versus temperature of combustion changes according to the nature of the polymer and to the presence of a flame inhibitor [1,4-7]. A correlation with the cone calorimeter test was also proposed [1].

It could be suggested that the combustion efficiency profile is related directly to the nature of combustible gases released during the pyrolysis. For this purpose, we have equipped our pyrolysis combustion flow calorimeter with a FTIR spectroscopy apparatus. The analysis of gases released during the thermal degradation of a polymer is usually performed by two well-known couplings, namely FTIR-thermogravimetric analysis (TGA) and FTIR-cone calorimetry. The former method makes it possible to analyze the gases released during pyrolysis before combustion: TG analysis is 
generally performed under nitrogen flow. Even if pyrolysis is carried out in an oxidative atmosphere, the polymer is degraded at relatively low temperatures (most often lower than $500^{\circ} \mathrm{C}$ ) and combustion does not occur to a great extent. Examples of the use of FTIR-TGA coupling to determine the degradation pathway can be found in the work of Schartel and co-workers [8,9]. FTIR-cone calorimetry coupling allows analyzing gases after combustion, but this combustion is not controlled. Combustion efficiency is generally close to 1 (complete combustion) except when flame inhibitors are incorporated into the polymer. This coupling is used for industrial purposes to measure the amounts of some released gases using a calibration method. An example of the use of this method can be found in the work of Lyon et al. [10]. To the best of our knowledge, no work about FTIR-PCFC coupling has been published yet. FTIR-PCFC coupling was presented by Sonnier et al. [11] during BCC2013. Lyon and Walters [12] have also studied a coupling between PCFC and a $\mathrm{CO}-\mathrm{CO}_{2}$ analyzer.

As mentioned above, in the PCFC test, pyrolysis and combustion are well separated and the combustion conditions can be modified independently. Therefore, FTIR-PCFC coupling should yield additional information about the combustion mechanisms. We believe that such coupling is complementary to FTIR-TGA and FTIR-cone calorimeter couplings. In this article, we present the first analyses obtained using FTIR-PCFC coupling.

\section{Materials and methods}

Polymers and additives used in this study are described in Table 1 . All products are commercially available. PA6/melamine cyanurate (MC) blend $75 / 25$ was prepared using a corotative twin-screw extruder (Clextral $\mathrm{BC} 21$; temperature profile ranges between 225 and $235^{\circ} \mathrm{C}$ ). PA6 was dried at $80^{\circ} \mathrm{C}$ for $4 \mathrm{~h}$ before processing.

PCFC tests were performed using a fire testing technology apparatus. Samples were heated under nitrogen flow up to $750{ }^{\circ} \mathrm{C}$ at a heating rate equal to $1 \mathrm{~K} / \mathrm{s}$. Gases were extracted and sent to a combustion chamber in the presence of $\mathrm{N}_{2} / \mathrm{O}_{2}(80 / 20)$ flow. For each experiment, sample weight was carefully selected in the range $2-5 \mathrm{mg}$ with a precision of $0.01 \mathrm{mg}$ to ensure that $\mathrm{O}_{2}$ was always in excess. The temperature of combustion was monitored between 600 and $900{ }^{\circ} \mathrm{C}$. Combustion efficiency at a temperature $T$ is calculated as follows

$\chi(T)=\Delta \mathrm{O}_{2}$ at the temperature $T / \Delta \mathrm{O}_{2}$ at $900{ }^{\circ} \mathrm{C}$,

where $\Delta \mathrm{O}_{2}$ at the temperature $T$ is the mass or volume of oxygen consumed at the combustor set point temperature $T$, and $\Delta \mathrm{O}_{2}$ at $900{ }^{\circ} \mathrm{C}$ is the oxygen consumed by combustion of the pyrolysis gases at $T=900^{\circ} \mathrm{C}$. As said previously, $900{ }^{\circ} \mathrm{C}$ is generally enough to ensure complete combustion.

The heat release rate is calculated from the oxygen consumption according to Huggett's relation ( $1 \mathrm{~kg}$ of consumed oxygen corresponds to $13.1 \mathrm{MJ}$ of released heat) [3]. Total heat release is equal to the area under the curve plotting the heat release rate versus the pyrolysis temperature. Therefore, combustion efficiency is practically calculated as follows:

Table 1

Polymers and additives used in this study.

\begin{tabular}{ll}
\hline Polymer or additive & Grade \\
\hline Polystyrene (PS) & Lacqrene 1340 (Arkema) \\
Poly(parabromostyrene) (PS-Br) & Aldrich \\
Polyamide 6 (PA6) & Technyl C216 (Rhodia) \\
Low-density polyethylene (LDPE) & Riblene FL20 (Polimeri Europa) \\
Melamine cyanurate (MC) & MC15 (Melapur) \\
Cellulose & Arbocell BC 1000 \\
Chloroprene & Baypren 116 (Lanxess) \\
\hline
\end{tabular}

$\chi(T)=$ total heat release at the temperature $\mathrm{T} /$ total heat release at $900{ }^{\circ} \mathrm{C}$.

Eqs. (1) and (2) are equivalent in this case.

It is noteworthy that pyrolysis conditions were never changed. Only the combustion efficiency of the gases released by pyrolysis was affected when the combustion temperature was modified. Repeatability of PCFC analyses is estimated to be 3\% [2] and is experimentally confirmed for our apparatus.

A Nicolet iS10 FTIR spectrometer from ThermoFisher Scientific was coupled at the exhaust of PCFC via a 2-m heated transfer line. The temperatures of the line transfer and of the gas cell were fixed at 160 and $165^{\circ} \mathrm{C}$, respectively. FTIR spectra $\left(400-4000 \mathrm{~cm}^{-1}\right.$ range, resolution fixed to $0.5 \mathrm{~cm}^{-1}$ ) were studied using Omnic software from ThermoFisher Scientific. The spectra acquisition uses a Gram-Schmidt vector of data orthogonalization, which is a particularly simple and direct approach. Gram-Schmidt processing can provide visualizations of spectroscopic imaging data in real time. A basis set consisting of background interferograms is established before the experiment is started. This basis set is then used to detect the presence of infrared-radiation-absorbing species in real time by comparing the sample interferograms to the basis set [13]. The Gram-Schmidt rebuilt from vector analysis of the acquired interferograms allows the total evolved gases detected by the spectrometer to be plotted. The detector signal has been plotted as a function of the pyrolysis temperature.

It must be noticed that gases are transferred from the tube furnace to the exhaust of the PCFC along a first nonheated transfer line including Drierite and an oxygen analyzer. As proved below, some gases adsorb before reaching the FTIR cell. Therefore, no accurate gas analysis is possible. Further work will be carried out to avoid the adsorption or condensation of gases and of water, which could solubilize some volatiles. Recommendations for a correct coupling system can be found elsewhere [14-16]. This work was done to develop the FTIR-cone calorimeter coupling. In particular, the choice of probe, filters, and sampling line (temperature, inner diameter, and length) was emphasized. Halogenated gases $(\mathrm{HCl}$ and even more extensively $\mathrm{HBr}$ ) are subjected to strong adsorption. In particular, a minimum temperature of $150^{\circ} \mathrm{C}$ along the entire sampling device is recommended [14]. It is not the case of our coupling and some gases are not detected (or only after a long unacceptable response time).

Cone calorimeter tests were performed using a FTT apparatus according to ISO 5660 standard. Irradiance was fixed at $35 \mathrm{~kW} /$ $\mathrm{m}^{2}$. The samples were embedded in aluminum foil and positioned in the standard sample holder. No grid was used. Ignition was piloted using a spark igniter except when thermocouples were used. An Antaris IGS FTIR spectrometer $\left(400-4000 \mathrm{~cm}^{-1}\right.$ range) from ThermoFisher Scientific was coupled to the cone calorimeter using a 2-m transfer line heated to $160^{\circ} \mathrm{C}$. The sampling point was located on the stack just before the sampling point for the oxygen analyzer. Filters were positioned to trap soot particles. Temperature and pressure conditions in the gas cell were fixed at $165^{\circ} \mathrm{C}$ and 650 Torr. FTIR spectra were studied using Omnic software from ThermoFisher Scientific.

Thermogravimetric analyses were carried out using a Pyris- 1 Perkin-Elmer apparatus. The heating rate was fixed at $10^{\circ} \mathrm{C} / \mathrm{min}$ under nitrogen flow up to $750^{\circ} \mathrm{C}$.

\section{Results and discussion}

If some combustible molecules are not fully oxidized during combustion, $\mathrm{CO}$ is produced (instead of $\mathrm{CO}_{2}$ ) and other not-fullyoxidized hydrocarbon gases could be released, such as methane. Nevertheless, in combustion, "the hydrocarbon is attacked by the $\mathrm{O}^{\circ}, \mathrm{H}^{\circ}$ and $\mathrm{OH}^{\circ}$ radicals. The larger alkyl radicals formed in this 
manner will then decompose to smaller alkyl radicals by fast elimination of alkenes. The rapidity of the decomposition of the larger alkyl radicals is such that the flame oxidation of all higher hydrocarbons centers about the oxidation of the methyl and ethyl radicals" [17].

Therefore, the FTIR spectra obtained using FTIR-PCFC coupling are simpler than those obtained using FTIR-TGA coupling because no large hydrocarbon molecules can be observed. First analyses detected the following gases: $\mathrm{CO}, \mathrm{CO}_{2}, \mathrm{CH}_{4}, \mathrm{HCl}, \mathrm{HCN}, \mathrm{NO}, \mathrm{N}_{2} \mathrm{O}$, $\mathrm{NO}_{2}, \mathrm{C}_{2} \mathrm{H}_{2}, \mathrm{C}_{2} \mathrm{H}_{4}$, and $\mathrm{C}_{2} \mathrm{H}_{4} \mathrm{O}$.

Thereafter, some examples will be presented in order to assess the usefulness but also the limits of FTIR-PCFC coupling.

The influence of various parameters (temperature, airflow rate, and oxygen concentration) on the gas yields was already studied using a combustion tube furnace $[18,19]$. The authors found that these parameters affect the thermal decomposition products qualitatively and quantitatively. It should be noticed that the pyrolysis was aerobic (contrary to our experiments). The temperature range was $400-800{ }^{\circ} \mathrm{C}$. While oxidation of gases almost does not occur at the lowest temperature, oxidation is intensive and most often complete at the highest one. This probably explains why the authors found a nonmonotonic evolution of some gases with the temperature (for example, $\mathrm{CO}$ yield is maximum at $600{ }^{\circ} \mathrm{C}$ for cotton and rayon). In contrast, in our case, $\mathrm{CO}$ yield decreases systematically when combustion temperature increases. Contrary to the combustion tube furnace, pyrolysis is not affected by changing the combustion conditions in PCFC. This is a great benefit of this apparatus.

\subsection{Critical temperature for complete combustion}

In a previous work [1], we have shown that the combustion of low-density polyethylene (LDPE) becomes complete between 700 and $750^{\circ} \mathrm{C}$, using a PCFC apparatus. The combustion efficiency was measured as 0.93 at $700{ }^{\circ} \mathrm{C}$ and 1 at $750^{\circ} \mathrm{C}$.

Figures 1 and 2 show the FTIR spectra of gases after pyrolysis of LDPE and combustion in PCFC, respectively, at 750 and $700^{\circ} \mathrm{C}$ at different times. The $\mathrm{CO}$ peak (between 2000 and $2200 \mathrm{~cm}^{-1}$ ) is not observed at $750{ }^{\circ} \mathrm{C}$ at any time. Only $\mathrm{CO}_{2}$ is observed, with bands between 2200 and $2400 \mathrm{~cm}^{-1}$ (Fig. 1). Bands located between 3500 and $3800 \mathrm{~cm}^{-1}$ and between 570 and $720 \mathrm{~cm}^{-1}$ are also attributed to $\mathrm{CO}_{2}$. In contrast, $\mathrm{CO}$ is released during the whole LDPE degradation at $700{ }^{\circ} \mathrm{C}$ (Fig. 2). Details of the FTIR spectrum recorded at the peak heat release rate are given in Fig. 3. The $2000-2500 \mathrm{~cm}^{-1}$ range corresponding to $\mathrm{CO}$ and $\mathrm{CO}_{2}$ peaks is shown. $\mathrm{CO}$ appears only at $700{ }^{\circ} \mathrm{C}$. These results confirm that combustion becomes complete between 700 and $750^{\circ} \mathrm{C}$. FTIR analysis is in qualitative agreement with combustion efficiency measurements.

\subsection{Example of incomplete combustion at $900{ }^{\circ} \mathrm{C}$}

Most generally, PCFC is used under standard conditions. This means that combustion occurs at a very high temperature $\left(900{ }^{\circ} \mathrm{C}\right)$ in an excess of oxygen. Under these conditions, combustion is believed to be complete [2]. FTIR-PCFC coupling can confirm this assertion: if the combustion is complete, only fully oxidized molecules are detected. In particular, carbon monoxide, which is typical of partial combustion, is not detected. Obviously, it is not possible to consider the combustion efficiency to check if the combustion is complete. Combustion efficiency is calculated as the ratio of the total heat release at a given temperature to the total heat release at $900^{\circ} \mathrm{C}$. Hence, combustion efficiency is, by definition, equal to 1 at $900{ }^{\circ} \mathrm{C}$.

Figure 4 shows the FTIR spectra obtained after combustion at the peak heat release rate for three polymers: polyamide 6 (PA6), polystyrene (PS), and polyparabromostyrene (PS-Br). The spectra
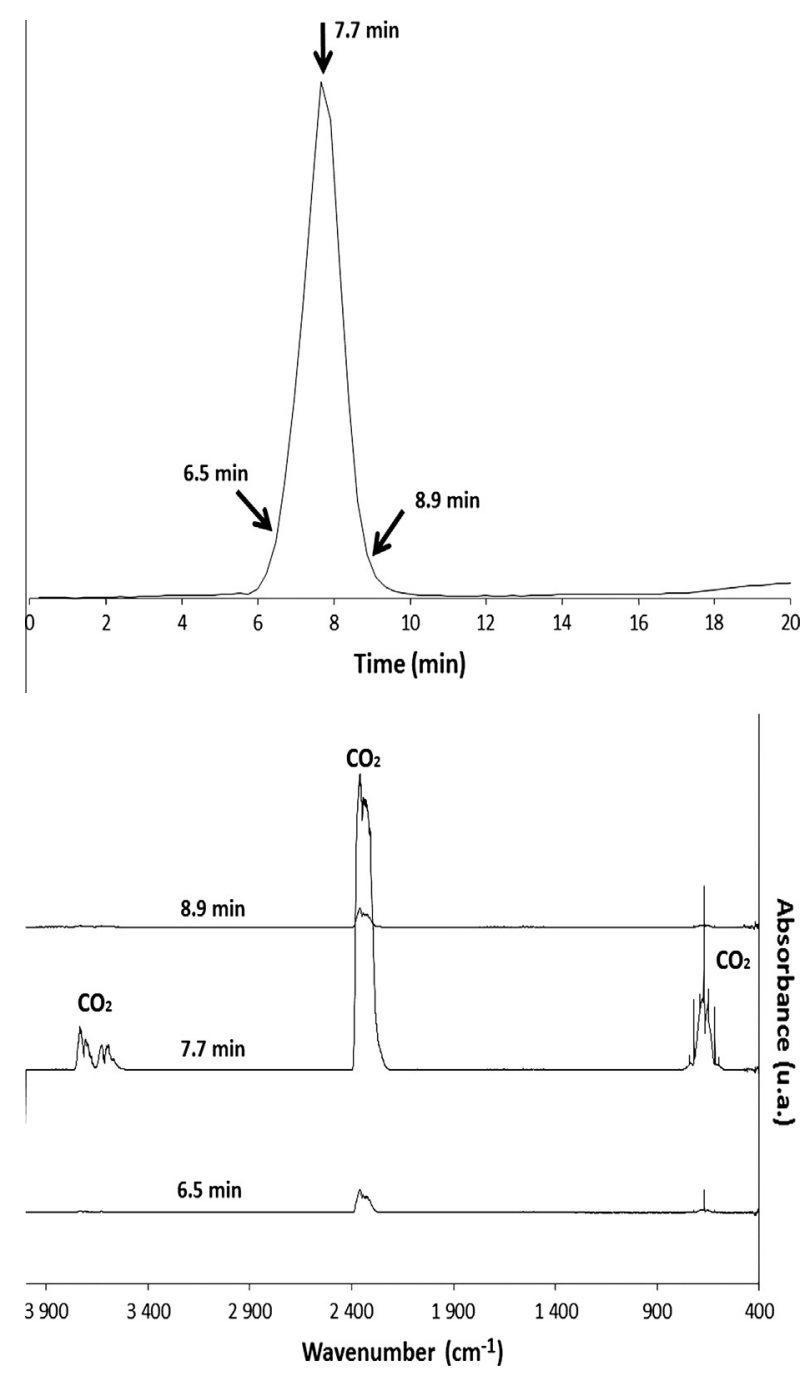

Fig. 1. Gram-Schmidt (top) and FTIR spectra (bottom) of gases after pyrolysis of LDPE and combustion at $750{ }^{\circ} \mathrm{C}$.

of the two first polymers exhibit only the presence of $\mathrm{CO}_{2}$ (bands between 2200 and $2400 \mathrm{~cm}^{-1}$ ) and $\mathrm{N}_{2} \mathrm{O}$ for PA6 (bands between 2130 and $2250 \mathrm{~cm}^{-1}$ ). In contrast, the spectrum of PS-Br exhibits not only $\mathrm{CO}_{2}$ bands but also $\mathrm{CO}$ bands (between 2000 and $2200 \mathrm{~cm}^{-1}$ ). This result allows concluding that combustion is not complete, even at $900{ }^{\circ} \mathrm{C}$ for PS-Br.

\subsection{Evidence of flame inhibition by bromine}

As shown in the previous example, the presence of bromine in PS macromolecules leads to incomplete combustion at high combustion temperatures. This well-known effect, called flame inhibition, is the main mode of action of halogenated flame retardants. Measurements of combustion efficiency and FTIR analysis of released gases make it possible to study this effect in detail. In this section, PS and PS-Br are compared at various combustion temperatures.

Both polymers exhibit pyrolysis in one step at close temperatures. The peak heat release rate temperature is $426^{\circ} \mathrm{C}$ for PS and $408^{\circ} \mathrm{C}$ for PS- $\mathrm{Br}$ (measured in PCFC at $1 \mathrm{~K} / \mathrm{s}$ ). Charring is negligible for both polymers (residue amount is $0 \mathrm{wt} \%$ for PS and less than $2.5 \mathrm{wt} \%$ for PS-Br). In contrast, combustion efficiency is significantly different for the two polymers (Fig. 5). Combustion of PS is complete when the combustion temperature is higher than $725^{\circ} \mathrm{C}$ 

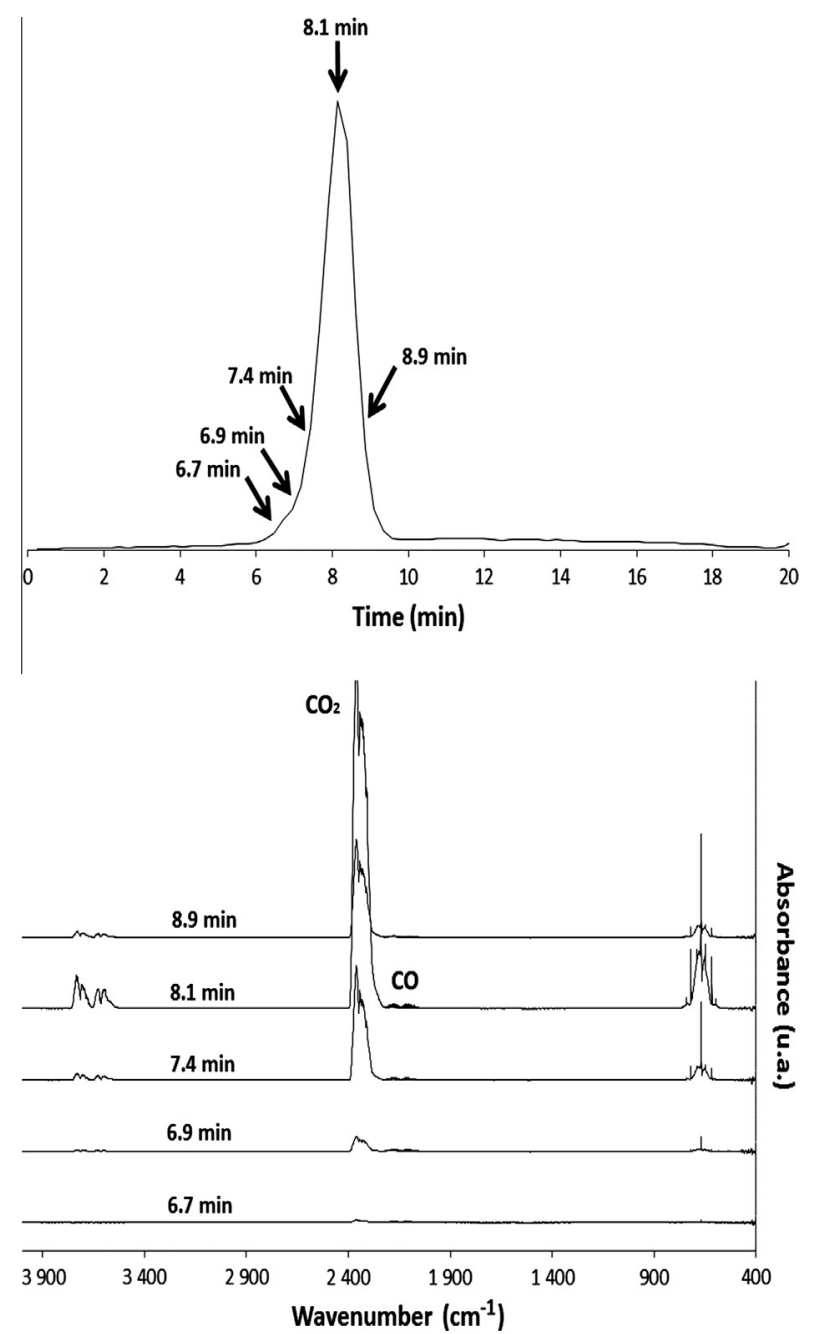

Fig. 2. Gram-Schmidt (top) and FTIR spectra (bottom) of gases after pyrolysis of LDPE and combustion at $700{ }^{\circ} \mathrm{C}$.

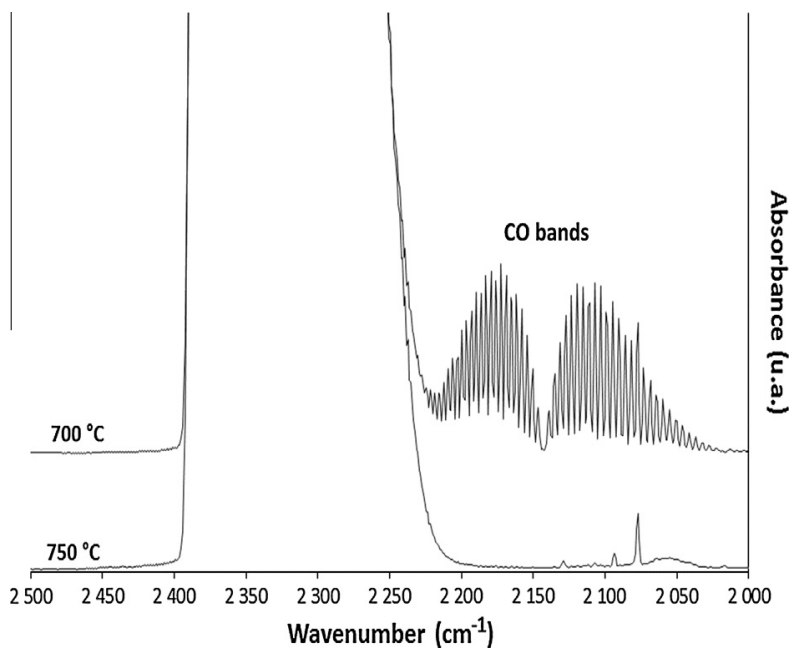

Fig. 3. Details of FTIR spectra of gases after pyrolysis of LDPE and combustion at 700 and $750{ }^{\circ} \mathrm{C}$ (at peak of heat release rate).

(energy of complete combustion equal to $34.7 \mathrm{~kJ} / \mathrm{g}$ ). Below this critical temperature, combustion efficiency decreases quickly to 0.21 at $600{ }^{\circ} \mathrm{C}$. Conversely, the critical temperature for complete combustion of $\mathrm{PS}-\mathrm{Br}$ is much higher. As seen in the previous sec-

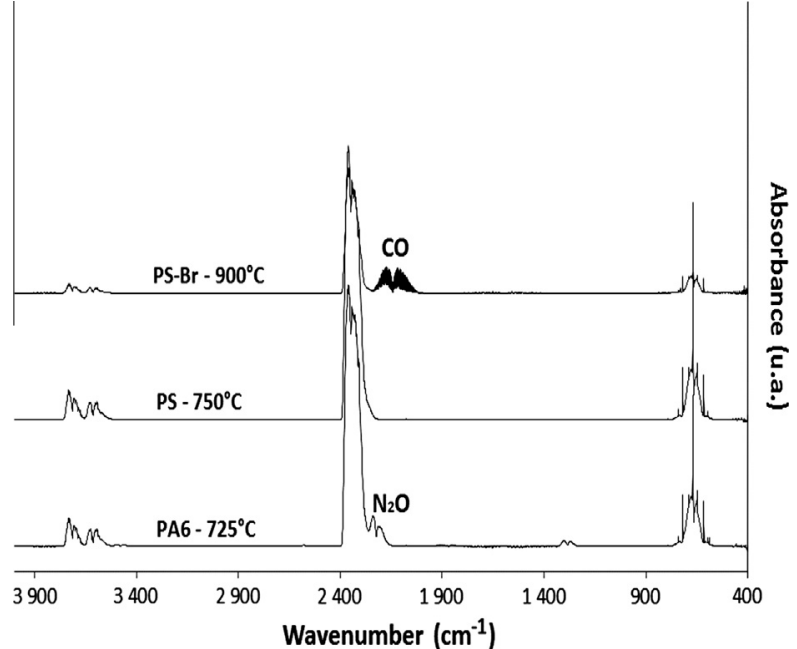

Fig. 4. FTIR spectra of gases after pyrolysis of PA6, PS, and PS-Br and combustion at 725,750 , and $900{ }^{\circ} \mathrm{C}$, respectively.

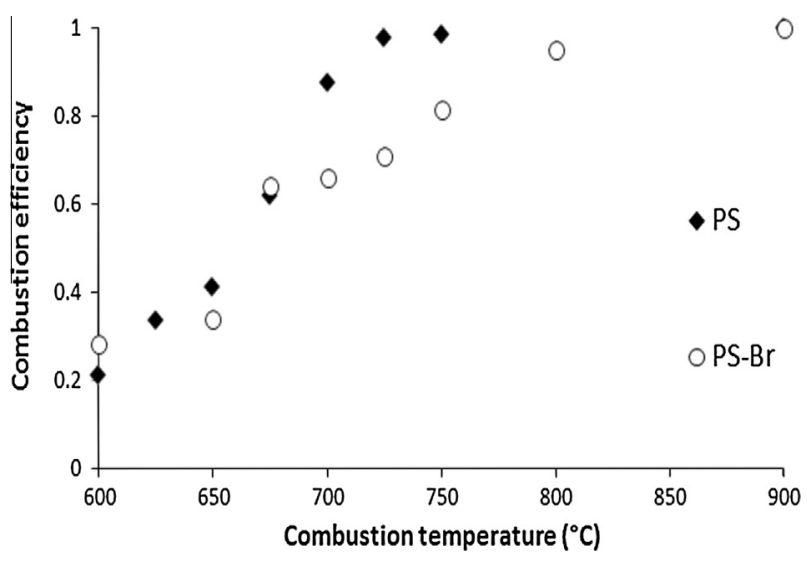

Fig. 5. Combustion efficiency versus combustion temperature for PS and PS-Br, measured using PCFC (anaerobic pyrolysis, $1 \mathrm{~K} / \mathrm{s}$ ).

tion, combustion is not complete even at $900^{\circ} \mathrm{C}$. Nevertheless, we calculated the combustion efficiency at each temperature assuming that combustion is complete at $900{ }^{\circ} \mathrm{C}$. Therefore, it is noteworthy that the calculated combustion efficiencies are slightly overestimated because the energy of complete combustion is higher than the value measured at $900{ }^{\circ} \mathrm{C}(12.3 \mathrm{~kJ} / \mathrm{g})$. At $700{ }^{\circ} \mathrm{C}$, calculated combustion efficiency is 0.65 (against 0.9 for PS). But below $675^{\circ} \mathrm{C}$, combustion efficiency appears to be similar for the two polymers $\left(0.21\right.$ and 0.28 at $600{ }^{\circ} \mathrm{C}, 0.34$ and 0.41 at $650{ }^{\circ} \mathrm{C}$, respectively, for PS and PS-Br).

FTIR analysis of gases is in qualitative agreement with the combustion efficiency measurements. Fig. 6 shows the FTIR spectra for PS and PS-Br at the peak heat release rate after combustion at various temperatures. At low combustion temperatures (600 and $650{ }^{\circ} \mathrm{C}$ ), CO release is clearly identified (bands at 2000$2200 \mathrm{~cm}^{-1}$ ). The ratio between $\mathrm{CO}$ and $\mathrm{CO}_{2}$ band areas is rather similar for the two polymers: 0.88 and 0.81 at $600{ }^{\circ} \mathrm{C}, 0.68$ and 0.77 at $650^{\circ} \mathrm{C}$, respectively, for PS and PS-Br. But at $700{ }^{\circ} \mathrm{C}, \mathrm{CO}$ bands have almost disappeared for FTIR spectra of PS. This confirms that the combustion of PS is almost complete at $700^{\circ} \mathrm{C}$ : the combustion efficiency is close to 0.9 . In contrast, the combustion efficiency of PS- $\mathrm{Br}$ at $700^{\circ} \mathrm{C}$ is low (close to 0.65) and the CO bands are much higher. The ratio $\mathrm{CO} / \mathrm{CO}_{2}$ is 0.017 for PS and 0.70 for PS- $\mathrm{Br}$ for this combustion temperature. This result points out the flame inhibition effect of bromine. 


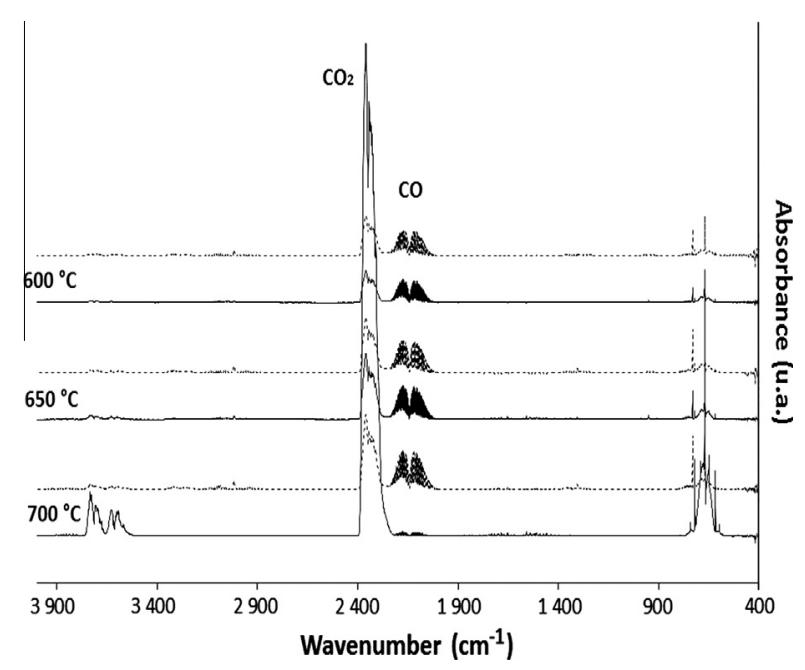

Fig. 6. FTIR spectra of gases released after pyrolysis of PS (solid line) and PS-Br (dotted line) and combustion at various temperatures and at the peak heat release rate.

The $2900-3200 \mathrm{~cm}^{-1}$ range was also found to be a relevant region in the FTIR spectra, since it corresponds to methane vibrations. Methane is a product of incomplete combustion. Figs. 7 and 8 show details in the range $3500-2900 \mathrm{~cm}^{-1}$ of FTIR spectra presented in Fig. 6. Methane is observed in FTIR spectra of PS at low temperatures (up to $650^{\circ} \mathrm{C}$ ). Above this temperature, methane is not seen any more. At $700^{\circ} \mathrm{C}$, combustion is almost complete; methane bands have disappeared, like CO bands. In contrast, methane is released up to a combustion temperature of $750{ }^{\circ} \mathrm{C}$ for $\mathrm{PS}-\mathrm{Br}$ (Fig. 8). Bands between 3200 and $3400 \mathrm{~cm}^{-1}$ are attributed to acetylene $\left(\mathrm{C}_{2} \mathrm{H}_{2}\right)$. Like $\mathrm{CO}$, acetylene and methane are good indicators of incomplete combustion. It is interesting to notice that $\mathrm{CO}$, acetylene, and methane release are not perfectly correlated. CO is still observed at higher temperatures ( 800 and $900{ }^{\circ} \mathrm{C}$-see for example Fig. 4) than acetylene and methane in the case of the pyrolysis and combustion of PS-Br.

\subsection{Decomposition of halogenated polymers: Evidence of gas adsorption}

As previously mentioned, our FTIR-PCFC coupling method does not allow an accurate analysis of gases and must be strongly modified to detect all gases. Indeed, FTIR analysis is performed at the

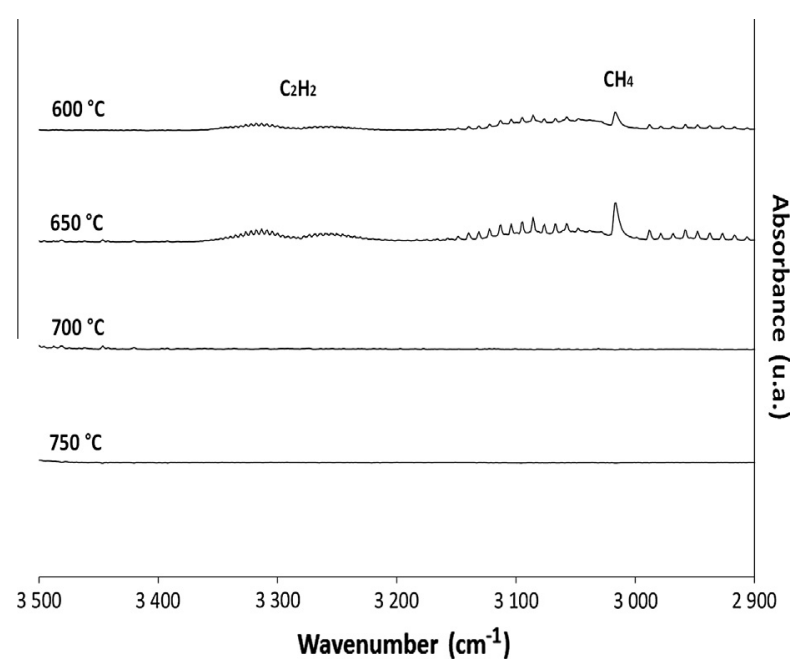

Fig. 7. Details of FTIR spectra of gases released after pyrolysis of PS and combustion at various temperatures and at peak heat release rate.

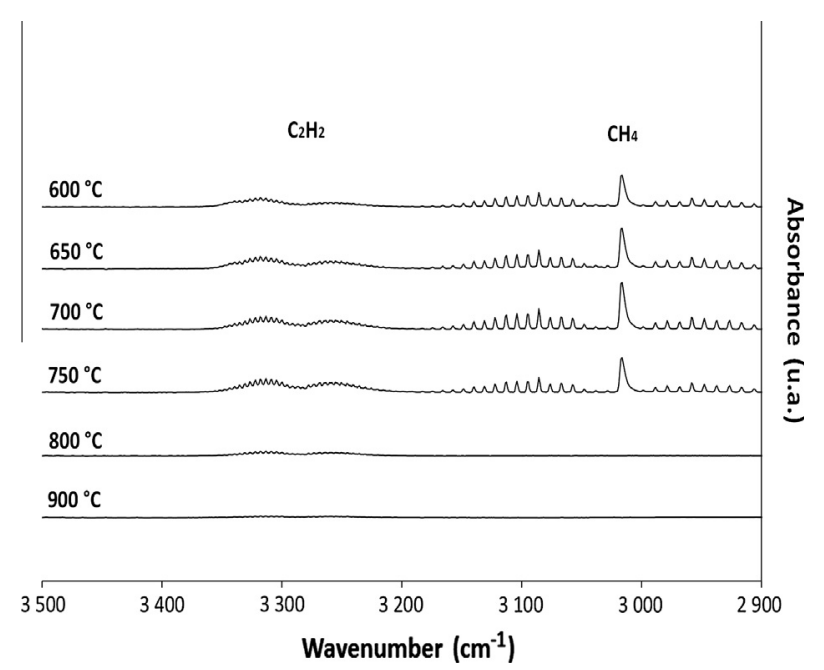

Fig. 8. Details of FTIR spectra of gases released after pyrolysis of PS-Br and combustion at various temperatures and at peak heat release rate.

exhaust of PCFC, i.e., after trapping of water by Drierite and with a long nonheated line transfer. Therefore, polar or high-molecular-weight gases could be adsorbed before the FTIR gas cell was reached.

We have previously presented the FTIR analysis of gases released from PS-Br pyrolysis. No brominated gases were detected, although the residue content of PS-Br was lower than 3 wt\% (measured using TGA-data not shown). This is evidence of adsorption of some gases before the FTIR gas cell is reached. Chlorinated gases released from the pyrolysis of poly(vinyl chloride) and polyparachlorostyrene followed by combustion respectively at 675 and $650{ }^{\circ} \mathrm{C}$ were not detected (data not shown).

In contrast, hydrogen chloride $(\mathrm{HCl})$ was detected in gases released from the pyrolysis of chloroprene after combustion at $650^{\circ} \mathrm{C}$ (Fig. 9). Combustion was not complete at this temperature, as shown by the presence of CO bands between 2000 and $2200 \mathrm{~cm}^{-1}$. Bands between 2900 and $3200 \mathrm{~cm}^{-1}$ confirm that methane was released during the whole decomposition, except at the very end of the degradation. Bands between 2700 and $3100 \mathrm{~cm}^{-1}$, partially overlapped with methane bands, showing that $\mathrm{HCl}$ was detected only after $8.2 \mathrm{~min}$, i.e., at the end of the decomposition of chloroprene.

Figure 10 shows the mass loss rate (measured in TGA) and the heat release rate of chloroprene (measured in PCFC). The first decomposition peak, located at $370{ }^{\circ} \mathrm{C}$, corresponds to a high mass loss (40 wt\% approximately) but a low heat release. In contrast, the second peak, located at $460{ }^{\circ} \mathrm{C}$, corresponds to a lower mass loss (32 wt\%) and a high heat release. Therefore, the effective heat of combustion (EHC) is lower for gases released during the first step of degradation than during the second step. This is in agreement with previous work [20-22]: the first main step of thermal decomposition of chloroprene, under an inert atmosphere, is the dehydrochlorination, which is also slightly observed during the second main step of decomposition [22]. Since no hydrogen chloride is detected during the first steps of decomposition, this result shows that this gas is partially adsorbed before reaching the FTIR gas cell.

\subsection{Flame inhibition or fuel dilution by melamine cyanurate?}

Melamine cyanurate is a well-known flame retardant for various polymers, particularly for PA6 [23-29]. Its main modes of action are an endothermic effect due to sublimation of melamine 

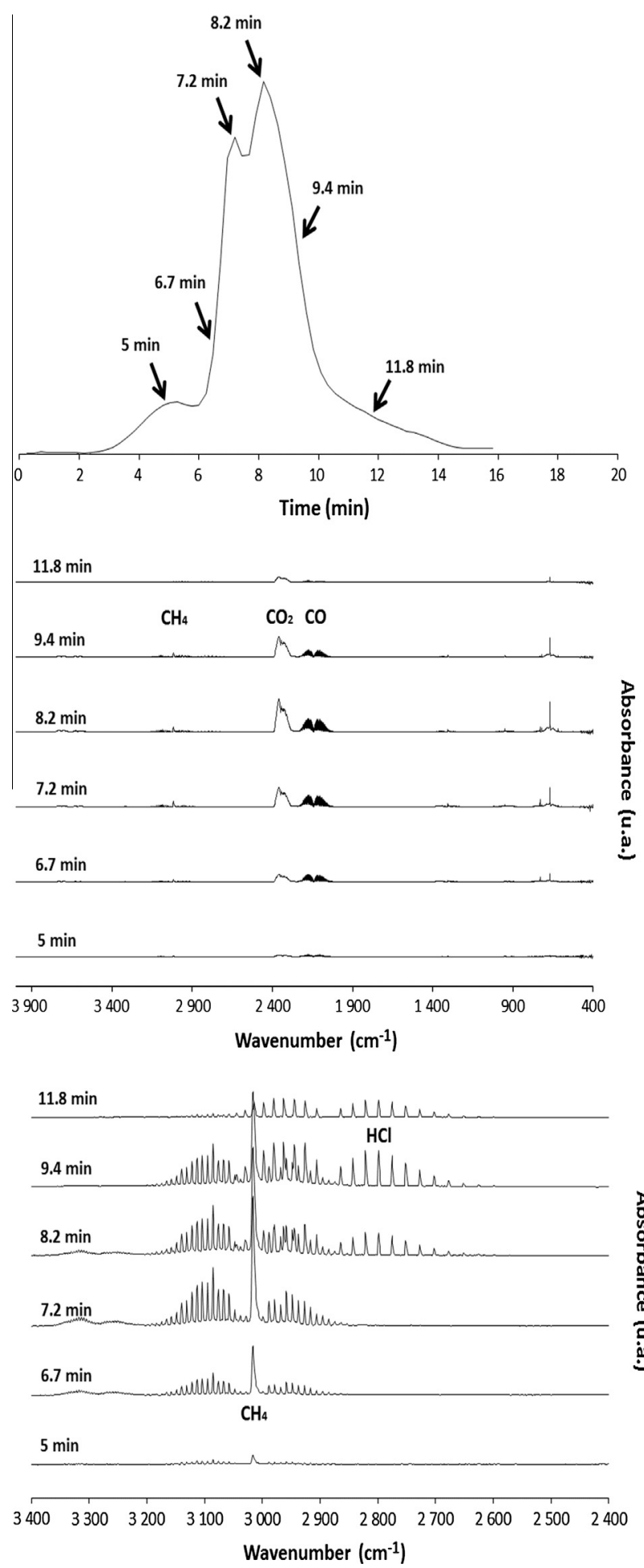

Fig. 9. Gram-Schmidt (top) and FTIR spectra (middle and bottom) of gases after pyrolysis of chloroprene and combustion at $650{ }^{\circ} \mathrm{C}$. Arrows indicate the times of FTIR analyses.

and degradation of cyanuric acid and melamine, dilution of fuel gases by melamine, dripping promotion, and interactions in condensed phase with the degradation products from the polymer pyrolysis. Flame inhibition is not considered as a mode of action of melamine cyanurate.

Figure 11 shows the FTIR spectra of gases released after pyrolysis of pure PA6 and combustion at different combustion temperatures. Above $700{ }^{\circ} \mathrm{C}$, combustion is complete, according to the

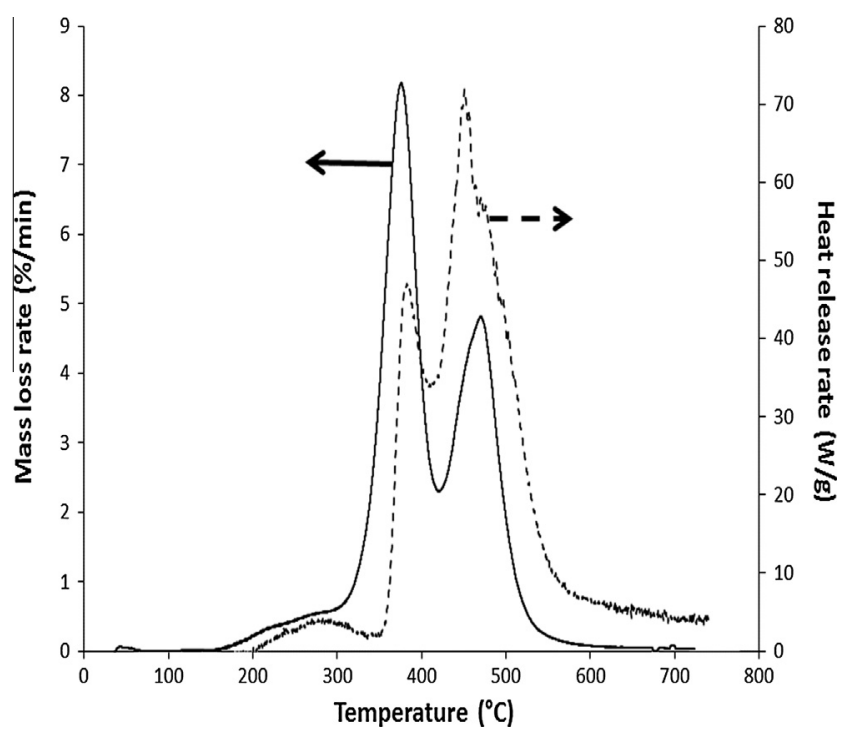

Fig. 10. Mass loss rate of chloroprene measured in TGA at $10^{\circ} \mathrm{C} / \mathrm{min}$ and heat release rate measured in PCFC at $1 \mathrm{~K} / \mathrm{s}$.

disappearance of $\mathrm{CO}$ bands at $2000-2200 \mathrm{~cm}^{-1}$. Various $\mathrm{NO}_{x}$ are observed, such as NO $\left(1800-1900 \mathrm{~cm}^{-1}\right), \mathrm{NO}_{2}\left(1550-1610 \mathrm{~cm}^{-1}\right)$, and $\mathrm{N}_{2} \mathrm{O}\left(2130-2250 \mathrm{~cm}^{-1}\right)$. CO is observed at temperatures lower than $700{ }^{\circ} \mathrm{C}$. Interestingly, combustible gases are observed at a very low combustion temperature $\left(600^{\circ} \mathrm{C}\right)$, such as acetylene, methane, and ethylene $\left(3200-3400,2900-3200\right.$, and $810-1050 \mathrm{~cm}^{-1}$, respectively).

Figure 12 shows the FTIR spectra of gases released after pyrolysis of melamine cyanurate and combustion at $900{ }^{\circ} \mathrm{C}$. Two main gases are identified: $\mathrm{CO}_{2}$ (bands at $2200-2400 \mathrm{~cm}^{-1}$ ) and isocyanic acid (HNCO at $2200-2300 \mathrm{~cm}^{-1}$ ). This gas is typical of the thermal decomposition of melamine compounds [30]. $\mathrm{N}_{2} \mathrm{O}$ is probably present but hardly identified due to overlap with HCNO peaks. $\mathrm{NH}_{3}$ was not detected. Traces of $\mathrm{CO}$ were observed according to the presence of small bands between 2000 and $2200 \mathrm{~cm}^{-1}$ (at least at 6.5 and $7.2 \mathrm{~min}$ ), which means that combustion was not complete, even at $900{ }^{\circ} \mathrm{C}$.

Figure 13 shows the change in combustion efficiency with combustion temperature for PA6 and PA6/MC 75/25 (black and white

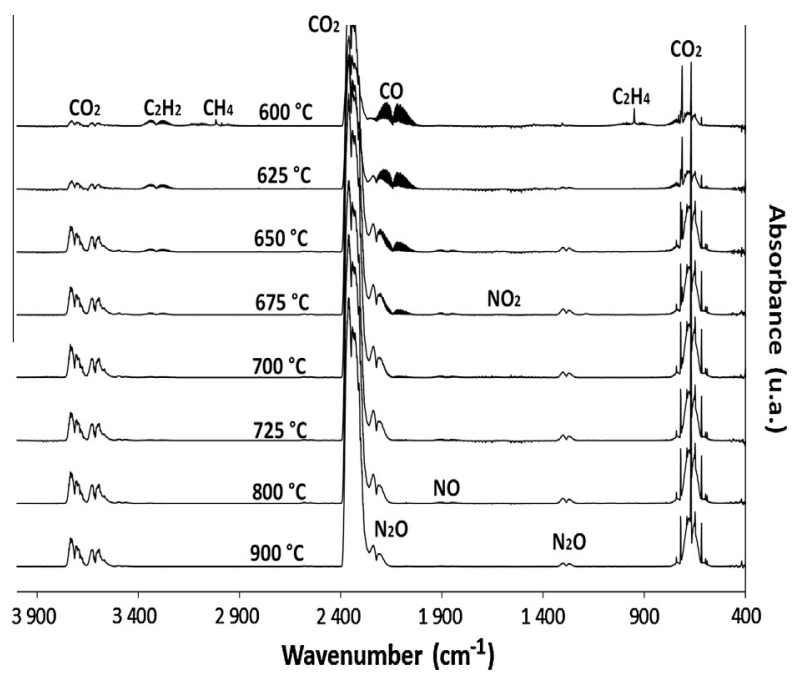

Fig. 11. FTIR spectra of gases released after pyrolysis of PA6 and combustion at various temperatures and at peak heat release rate. 

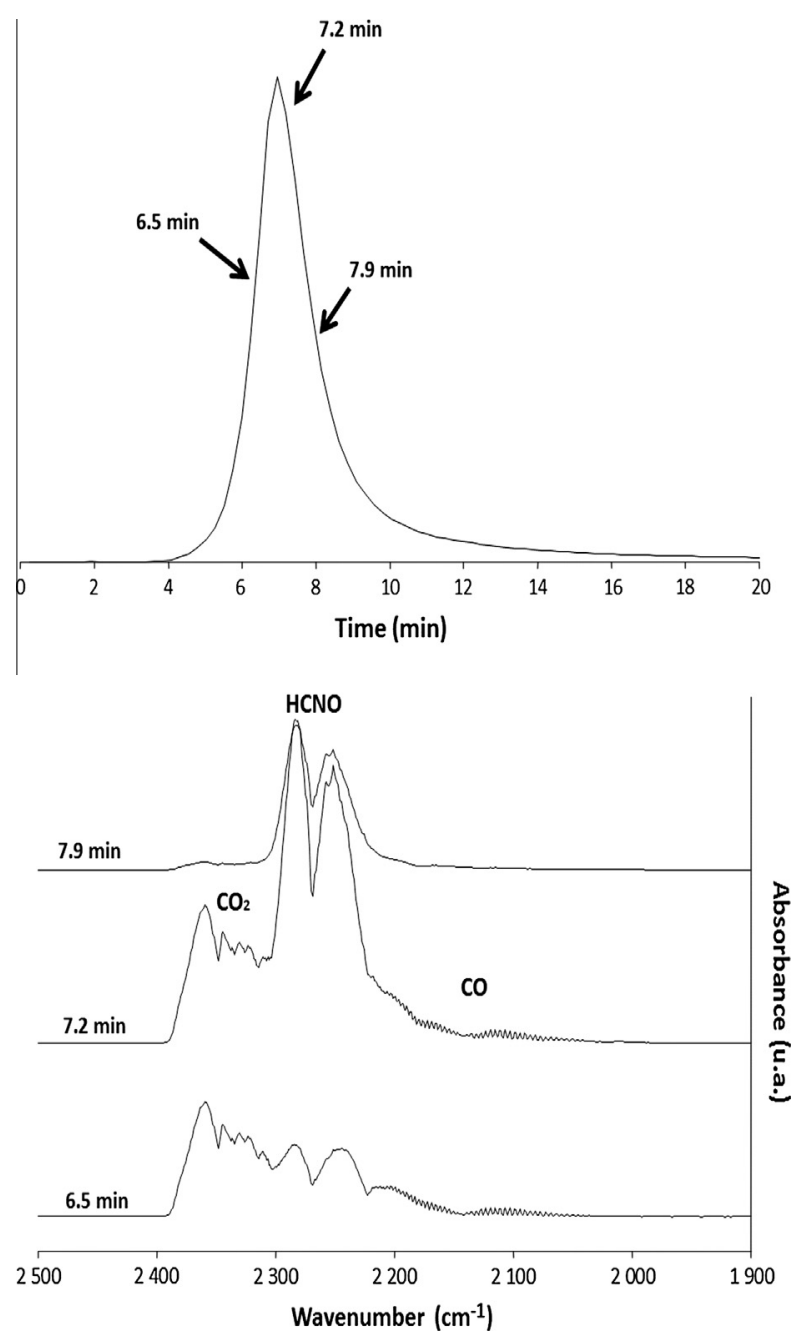

Fig. 12. Gram-Schmidt (top) and FTIR spectra (bottom) of gases after pyrolysis of melamine cyanurate and combustion at $900{ }^{\circ} \mathrm{C}$.

points, respectively). At 700 and $650{ }^{\circ} \mathrm{C}$, combustion efficiency is significantly lower for PA6/MC than for PA6. Total heat release at $900{ }^{\circ} \mathrm{C}$ is close to $25 \mathrm{~kJ} / \mathrm{g}$ for PA6 and $3.5-4 \mathrm{~kJ} / \mathrm{g}$ for melamine cyanurate. Even assuming that the combustion of melamine cyanurate would be zero at 650 and $700{ }^{\circ} \mathrm{C}$, the combustion efficiencies of the $\mathrm{PA6} / \mathrm{MC}$ blend according to a linear rule of mixtures (gray points in

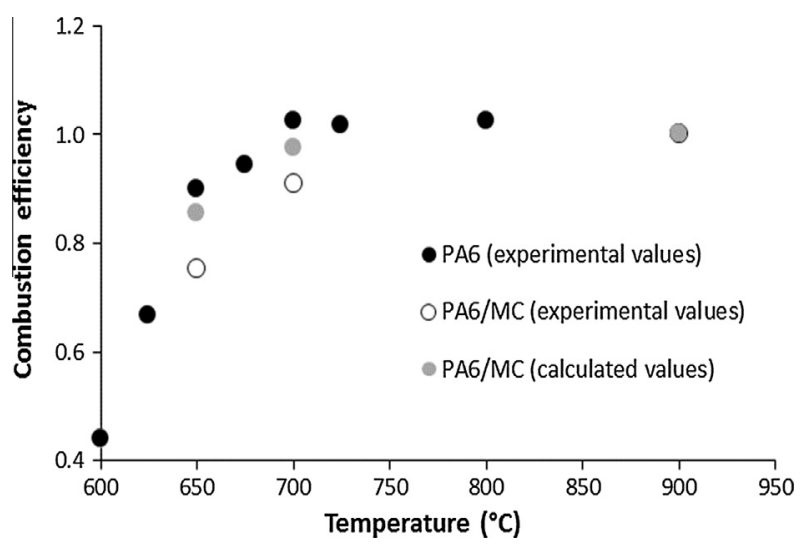

Fig. 13. Combustion efficiency versus combustion temperature for PA6 and PA6/MC blend, measured using PCFC (anaerobic pyrolysis, $1 \mathrm{~K} / \mathrm{s}$ ).
Fig. 13) are higher than the experimental values. Therefore, melamine cyanurate seems to exhibit a flame inhibition effect.

The FTIR spectra of gases after pyrolysis and combustion at 650 and $700{ }^{\circ} \mathrm{C}$ of PA6 and PA6/MC blend are shown in Fig. $14 . \mathrm{CO}_{2}$ bands are observed at 2200-2400 $\mathrm{cm}^{-1}$. $\mathrm{N}_{2} \mathrm{O}$ from PA6 decomposition is also present $\left(2130-2250 \mathrm{~cm}^{-1}\right)$. HNCO bands are not clearly identified due to overlapping of $\mathrm{CO}_{2}$ and $\mathrm{N}_{2} \mathrm{O}$ bands. $\mathrm{CO}$ bands are present $\left(2000-2200 \mathrm{~cm}^{-1}\right)$. CO bands are slightly more intense for PA6/MC than for pure PA6 at both combustion temperatures. Therefore, it seems that the combustion is more incomplete in the presence of MC, which would indicate that MC has a slight (but not negligible) flame inhibition effect in PA6.

This conclusion is highly speculative, while no flame inhibition effect of MC is reported in the literature. Another hypothesis can be proposed, assuming that combustion is a kinetic phenomenon occurring in limited time in PCFC (combustor residence time is $10 \mathrm{~s}$ ). Flame inhibition is not the only mode of action able to slow down the combustion. Fuel dilution can probably also lead to the same effect. If this effect is significant enough, combustion needs more than $10 \mathrm{~s}$ at a given temperature to be complete. Therefore the combustion efficiency would decrease. While fuel dilution is a well-known effect of MC, this assumption should be considered first.

\subsection{Combustion of gases released from cellulose pyrolysis- Comparison between FTIR-cone calorimetry and FTIR-PCFC coupling}

PCFC and cone calorimetry results are not necessarily correlated, and contradictory reports have been published about the comparison between the two tests [31-42]. But some works have shown that PCFC can help to evaluate the efficiency of flame retardants in cone calorimeter tests [1,31]. A review about this point can be found elsewhere [43]. The following experimental work was carried out to compare the FTIR-PCFC and FTIR-cone calorimetry couplings. It should be noted that the residence time in the PCFC combustor at a given temperature (not higher than $900^{\circ} \mathrm{C}$ ) is $10 \mathrm{~s}$. In the cone calorimeter, the residence time in the hydrocarbon diffusion flame is a few milliseconds, while its temperature is not homogeneous but as high as $1500^{\circ} \mathrm{C}$. Since the temperature has a great influence not only on the combustion kinetics but also on the reaction pathways, it should be quite difficult to compare the combustion in the two tests. Therefore the study below

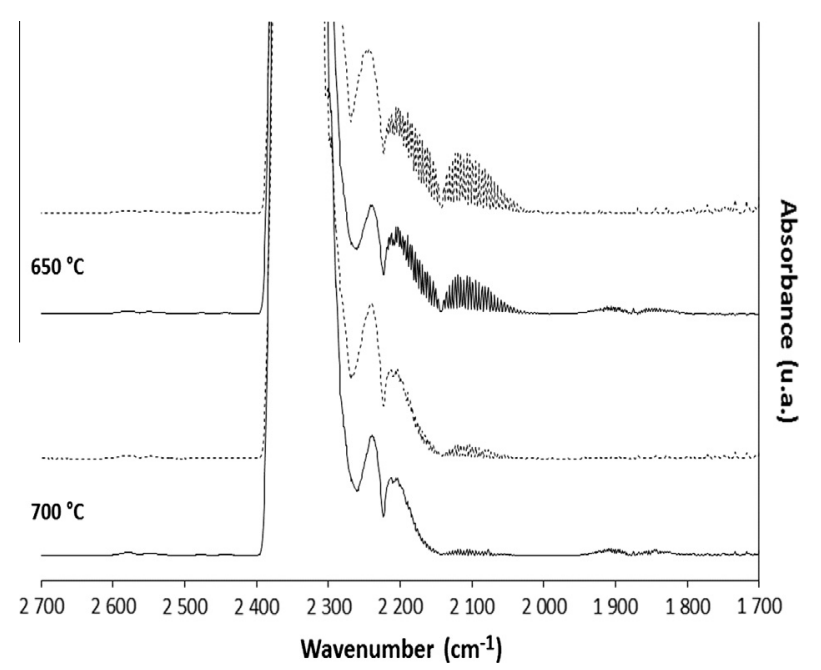

Fig. 14. FTIR spectra of gases released after pyrolysis of PA6 (solid line) and PA6/MC blend (dotted line) and combustion at 650 and $700{ }^{\circ} \mathrm{C}$ at peak heat release rate. 


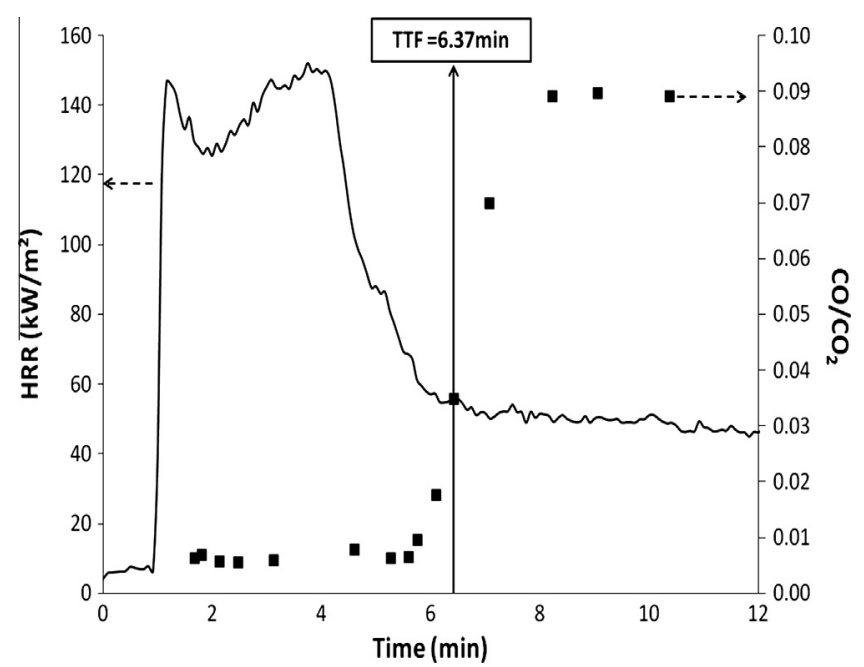

Fig. 15. HRR versus time at an irradiance of $35 \mathrm{~kW} / \mathrm{m}^{2}(-)$ and a $\mathrm{CO} / \mathrm{CO}_{2}$ ratio obtained during the cone calorimeter test ( $\mathbf{\square})$.

(including the concept of isoconversion temperature already published $[1,12]$ ) is not assessed theoretically.

Cellulose is the most extensively used natural polymer. Nevertheless, it burns easily and its fire behavior needs to be improved for many applications. Its thermal degradation has been widely studied in the literature $[44,45]$. Two competitive pathways of degradation have been proposed: dehydration and depolymerization. When dehydration prevails, release of $\mathrm{CO}_{2}, \mathrm{H}_{2} \mathrm{O}$, and $\mathrm{CO}$ with formation of solid char is observed. If depolymerization prevails, volatilization of tar, mostly composed of levoglucosan, is observed. The percentage of mass residue obtained by TGA under nitrogen flow at $700{ }^{\circ} \mathrm{C}$ is $10 \mathrm{wt} \%$ and the effective heat of complete combustion in PCFC is around $13.7 \mathrm{~kJ} / \mathrm{g}$ [46].

To evaluate the fire behavior of cellulose, samples were compression-molded to make cone calorimeter test specimens ( $25 \mathrm{~g}$ ) [46]. A cone calorimeter test was carried out at $35 \mathrm{~kW} / \mathrm{m}^{2}$ under standard conditions. Concentrations of released gases (especially $\mathrm{CO}$ and $\mathrm{CO}_{2}$ ) were measured using FTIR coupled to a cone calorimeter.

In the following, $\mathrm{CO} / \mathrm{CO}_{2}$ ratios in cone calorimetry and in PCFC are calculated from the area of bands at $2250-2400 \mathrm{~cm}^{-1}$ for $\mathrm{CO}_{2}$ and at $2000-2250 \mathrm{~cm}^{-1}$ for $\mathrm{CO}$ without taking into account the absorption coefficients. Of course these coefficients are not the same for the two gases, and therefore these ratios do not correspond to the ratios between the amounts (in ppm) of $\mathrm{CO}$ and $\mathrm{CO}_{2}$. Nevertheless, the absorption coefficients of $\mathrm{CO}$ and $\mathrm{CO}_{2}$ are assumed to be in the same ratio in PCFC and in cone calorimetry. According to this assumption, the $\mathrm{CO} / \mathrm{CO}_{2}$ ratios in the two devices can be compared. This approach was chosen while no calibration was attempted to estimate the amounts (in ppm) of $\mathrm{CO}$ and $\mathrm{CO}_{2}$ in FTIR-PCFC.

Figure 15 shows the curve of HRR versus time for cellulose. HRR increases after ignition and two peaks of HRR are observed at 140$150 \mathrm{~kW} / \mathrm{m}^{2}$. After the second peak at $4 \mathrm{~min}$, HRR decreases faster, up to $50 \mathrm{~kW} / \mathrm{m}^{2}$ at $6.37 \mathrm{~min}$ (corresponding to "time to flame out" (TTF)). After flame out, HRR is stable (around $50 \mathrm{~kW} / \mathrm{m}^{2}$ ) due to thermal oxidation of char.

Figure 15 also shows the $\mathrm{CO} / \mathrm{CO}_{2}$ ratio as a function of time. The ratio is constant and equal to 0.0064 during burning. After the flame out, the ratio increases to 0.0894 . This evolution indicates that the release of $\mathrm{CO}$ increases when the flame fades out. Flame out corresponds primarily to a switch from anaerobic to aerobic pyrolysis. Nevertheless, this change does not explain why the combustion becomes highly incomplete. If the temperature were high enough above the sample, gases from aerobic pyrolysis would be fully oxidized and $\mathrm{CO} / \mathrm{CO}_{2}$ should remain very low. This significant decrease in combustion efficiency is more probably due to the decrease of the temperature when the flame disappears.

To measure the temperature of the "combustion zone" during the cone calorimeter test, the apparatus was equipped with two thermocouples (Fig. 16). In this test, the cellulose was still exposed to an irradiance of $35 \mathrm{~kW} / \mathrm{m}^{2}$, but without a spark igniter.

Ignition occurs at $1 \mathrm{~min}$, leading to a quick increase in the temperature. During the burning, the temperature in the combustion zone ranges between 550 and $850^{\circ} \mathrm{C}$ (Fig. 17). After flame out (TTF), the temperature decreases from $400-700$ to $350-650{ }^{\circ} \mathrm{C}$ after a few minutes. This evolution is in accordance with the increase in the $\mathrm{CO} / \mathrm{CO}_{2}$ ratio due to a significant decrease in combustion efficiency.

In a previous work, we defined the isoconversion temperature in a cone calorimeter test as the temperature of combustion in PCFC for which the combustion efficiency is the same in both tests [1]. It could correspond to a mean temperature in the combustion zone in cone calorimeter. Fig. 18 shows the change in combustion efficiency and in $\mathrm{CO} / \mathrm{CO}_{2}$ ratio measured in PCFC with FTIR-PCFC coupling. As explained above, the $\mathrm{CO} / \mathrm{CO}_{2}$ ratios were determined from the band area at $2250-2400 \mathrm{~cm}^{-1}$ for $\mathrm{CO}_{2}$ and at 2000$2250 \mathrm{~cm}^{-1}$ for $\mathrm{CO}$ (without taking into account the absorption coefficients of gases).

Combustion efficiency decreases when combustion temperature is lower than $725^{\circ} \mathrm{C}$. Its value is almost 0.5 at $600{ }^{\circ} \mathrm{C}$. The $\mathrm{CO} / \mathrm{CO}_{2}$ ratio is extremely low for combustion temperatures higher than $725^{\circ} \mathrm{C}$ but increases faster when temperature decreases below this critical value.

The combustion efficiency obtained in the cone calorimeter test is calculated according to the following equation:

$$
\chi(\text { cone })=\mathrm{EHC}(\text { cone }) / \mathrm{EHC}\left(\mathrm{PCFC}_{900^{\circ} \mathrm{C}}\right)=10.9 / 11.8=0.92 .
$$

A combustion efficiency of 0.92 corresponds to a temperature of combustion close to $720^{\circ} \mathrm{C}$ in PCFC. This temperature is the isoconversion temperature and falls into the temperature range obtained using the thermocouples during the burning. Therefore, the isoconversion temperature in the cone calorimeter, calculated according to combustion efficiency in PCFC, is in good agreement with the temperatures of the combustion zone measured experimentally using thermocouples.

The comparison of the $\mathrm{CO} / \mathrm{CO}_{2}$ ratio (Fig. 15) in the cone calorimeter test (before and after the flame out) and the $\mathrm{CO} / \mathrm{CO}_{2}$ ratio obtained using the FTIR-PCFC coupling is shown in Fig. 19. The $\mathrm{CO} / \mathrm{CO}_{2}$ ratio for the cone calorimeter before flame out is equal to the $\mathrm{CO} / \mathrm{CO}_{2}$ for PCFC at a combustion temperature of $710^{\circ} \mathrm{C}$. This value corresponds quite well to the isoconversion temperature calculated previously from the combustion efficiency and to the temperature range of the combustion zone measured using thermocouples.

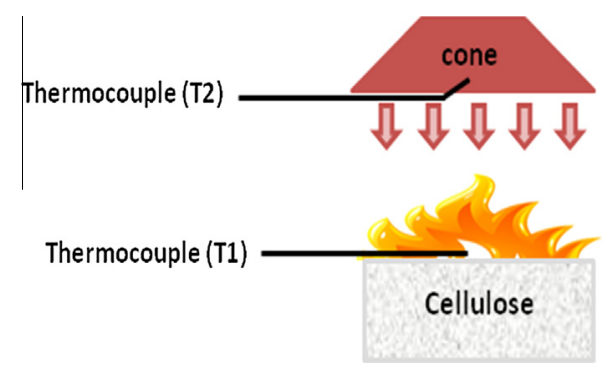

Fig. 16. Position of thermocouples in the combustion zone during the cone calorimeter test. 


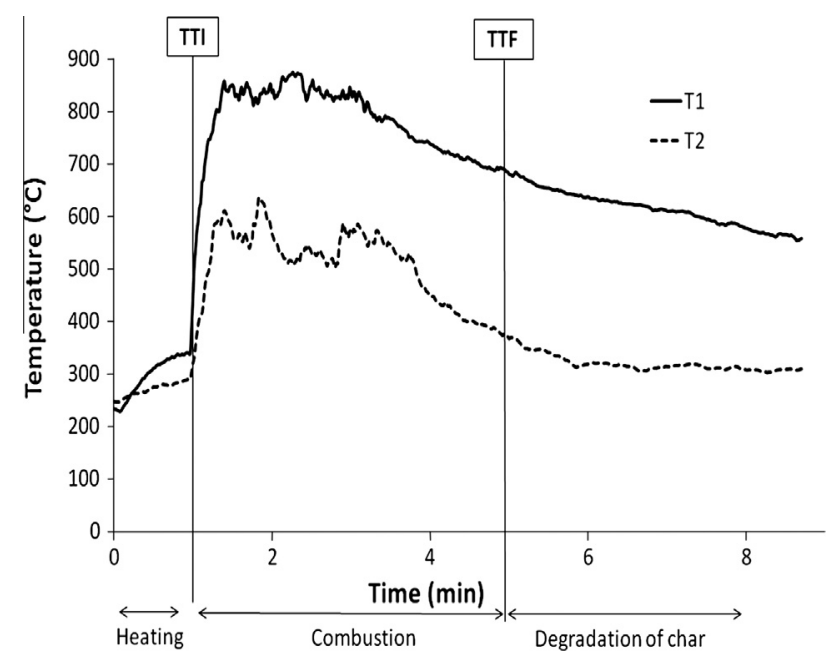

Fig. 17. Temperatures obtained by two thermocouples during the cone calorimeter test (without spark igniter). TTI: time to ignition.

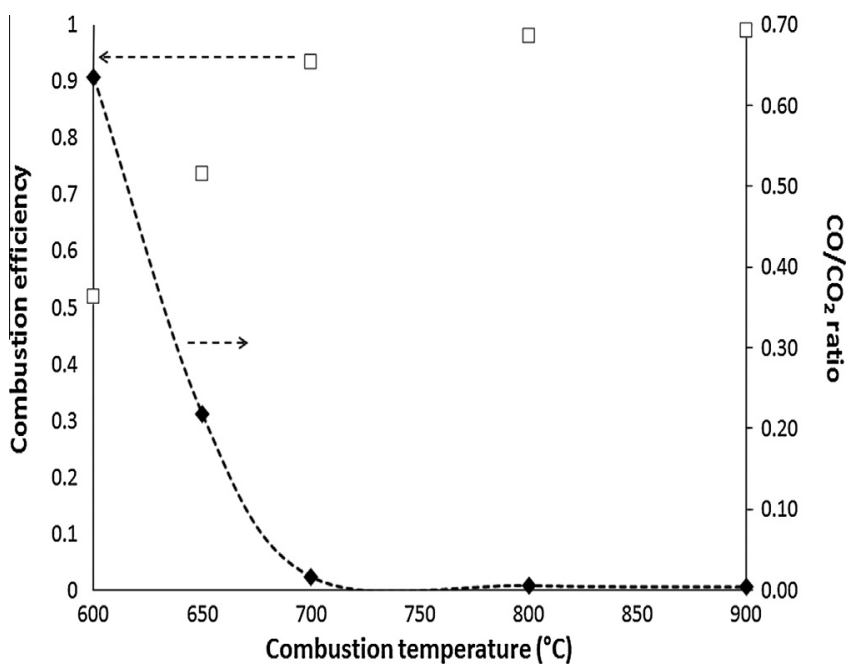

Fig. 18. Combustion efficiency and $\mathrm{CO} / \mathrm{CO}_{2}$ ratio versus the temperature of combustion for cellulose, measured using PCFC (anaerobic pyrolysis, $1 \mathrm{~K} / \mathrm{s}$ ).

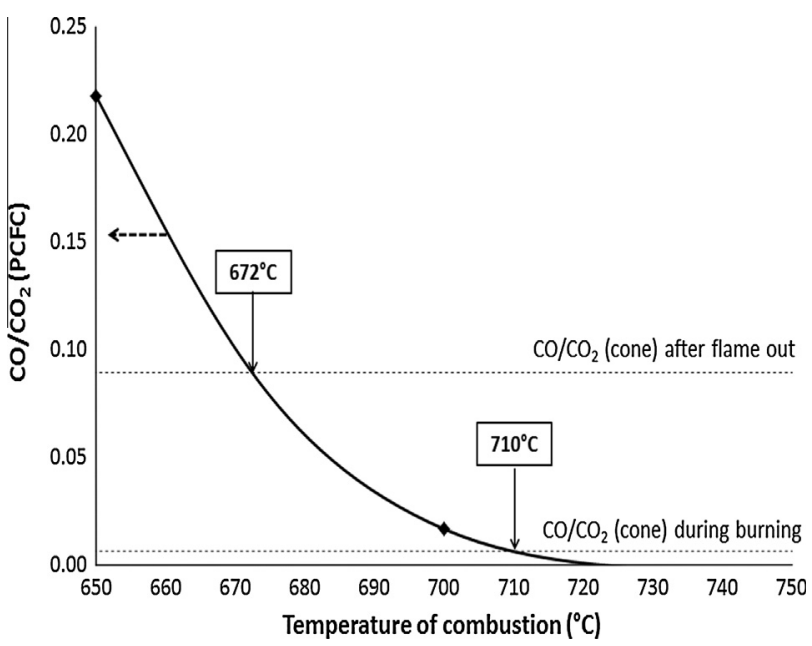

Fig. 19. Comparison of $\mathrm{CO} / \mathrm{CO}_{2}$ ratio obtained in FTIR-cone calorimeter and FTIRPCFC coupling.
The $\mathrm{CO} / \mathrm{CO}_{2}$ ratio for cone calorimetry after flame out corresponds obviously to a lower temperature $\left(672^{\circ} \mathrm{C}\right)$. Once again, this temperature is in good agreement with the upper temperature range measured after flame out using thermocouples $\left(650-700{ }^{\circ} \mathrm{C}\right)$.

The estimation of the combustion temperature in the cone calorimeter is carried out using three different methods: comparing the combustion efficiencies in the cone and in PCFC, comparing the $\mathrm{CO} / \mathrm{CO}_{2}$ ratios in the cone and in PCFC, and measuring temperatures above the sample during the cone test using thermocouples. These three methods seem to be in good agreement. This result supports the notion of isoconversion temperature in cone calorimeter and confirms that PCFC (and FTIR-PCFC coupling) would allow evaluating the fire behavior of a material tested using cone calorimetry. Nevertheless, it is very important to keep in mind that combustion occurs in a very different way in PCFC and in cone calorimetry, as said above. The concept of isoconversion temperature is not theoretically established.

\section{Conclusions}

For the first time, FTIR spectroscopy has been coupled to PCFC to investigate the combustion of polymers. FTIR-PCFC coupling appears clearly complementary to FTIR-TGA or FTIR-cone calorimeter ones. FTIR-PCFC allows studying the behavior of pyrolytic gases under well-controlled conditions of combustion, i.e., determining at which temperature these gases are oxidized.

$\mathrm{CO}$ is the most specific gas released in the case of incomplete combustion. As shown in the experiments carried out, its release is well correlated with the combustion efficiency measured in PCFC. Moreover, FTIR-PCFC allowed identifying incomplete combustion even at very high temperatures of combustion in the case of poly(parabromostyrene). In some cases, not only CO but also other gases, showing incomplete combustion, were identified, such as methane. The release of the two gases ( $\mathrm{CO}$ and methane) was not perfectly correlated.

FTIR-PCFC coupling is obviously well adapted to the study of flame inhibition, one of the main mode of actions of flame retardants, particularly halogenated compounds. An unexpected decrease in combustion efficiency by melamine cyanurate has been also highlighted, which can more probably be assigned to fuel dilution.

A first approach was carried out to compare FTIR-cone and FTIR-PCFC coupling. It appears that the temperature of the combustion zone in cone calorimetry could be estimated in PCFC using the combustion efficiency curve, but also the $\mathrm{CO} / \mathrm{CO}_{2}$ ratios. This approach needs further work to be completely reliable but, once again, PCFC analyses should help to understand and/or predict the fire behavior of a material investigated using cone calorimetry.

Since the FTIR spectrometer was coupled to the exhaust of the pyrolysis combustion flow calorimeter, the coupling is not optimal, due to trapping of water by Drierite and adsorption of polar or high-molecular-weight gases. In particular, hydrogen bromide and chloride were not (or were only partially) found by FTIR spectroscopy. Further work will be carried out to couple the FTIR spectrometer directly to the exhaust of the combustor to limit the adsorption of gases.

\section{References}

[1] R. Sonnier, B. Otazaghine, L. Ferry, J.M. Lopez-Cuesta, Combust. Flame 60 (2013) 2182-2193.

[2] R.E. Lyon, R.N. Walters, J. Anal. Appl. Pyrolysis 71 (2004) 27-46.

[3] C. Huggett, Fire Mater. 4 (1980) 61-65.

[4] R.E. Lyon, R.N. Walters, in: Fire and Materials Conference, San Francisco, CA January 28-30, 2013.

[5] R.E. Lyon, R.N. Walters, S.I. Stoliarov, J. ASTM Int. 3 (4) (2006) 1-18.

[6] R.N. Walters, R.E. Lyon, in: 40th Meeting of the North American Thermal Analysis Society, Orlando, FL, August 12-15, 2012. 
[7] B. Schartel, K.H. Pawlowski, R.E. Lyon, Thermochim. Acta 462 (2007) 1-14.

[8] K.H. Pawlowski, B. Schartel, Polym. Int. 56 (2007) 1404-1414.

[9] U. Braun, A.I. Balabanovich, B. Schartel, U. Knoll, J. Artner, M. Ciesielski, M. Doring, R. Perez, J.K.W. Sandler, V. Altstadt, T. Hoffmann, D. Pospiech, Polymer 47 (2006) 8495-8508.

[10] R.E. Lyon, L. Speitel, R.N. Walters, S. Crowley, Fire Mater. 27 (2003) 195-208.

[11] R. Sonnier, G. Dorez, H. Vahabi, C. Longuet, L. Ferry, in: 24th Annual Conference on Recent Advances in Flame Retardancy of Polymeric Materials, Stamford, USA, 2013.

[12] R.E. Lyon, R.N. Walters, in: 24th Annual Conference on Recent Advances in Flame Retardancy of Polymeric Materials, Stamford, USA, 2013.

[13] R. Bhargava, I.W. Levin, Appl. Spectrosc. 58 (2004) 995-1000.

[14] T. Hakkarainen, The SAFIR Project, VTT Technical Research Centre of Finland, Espoo, 1999.

[15] L. Speitel, in: 46th International SAMPE Symposium, Long Beach, USA, 2001.

[16] L. Speitel, Report DOT/FAA/AR-01/88, 2001.

[17] V. Babushok, W. Tsang, Combust. Flame 123 (2000) 488-506.

[18] J.C. Spurgeon, L.C. Speitel, R.E. Feher, J. Fire Flammability 8 (1977) 349-363.

[19] J.C. Spurgeon, L.C. Speitel, R.E. Feher, Report FAA-RD-77-20, 1977.

[20] M. Mehl, A. Marongiu, T. Faravelli, G. Bozzano, M. Dente, E. Ranzi, J. Anal. Appl. Pyrolysis 72 (2004) 253-272.

[21] I. Aracil, R. Font, J.A. Conesa, A. Fullana, J. Anal. Appl. Pyrolysis 79 (2007) 327 336.

[22] K. Subramaniam, A. Das, L. Haubler, C. Harnisch, K.W. Stockelhuber, G. Heinrich, Polym. Degrad. Stab. 97 (2012) 776-785.

[23] S.V. Levchik, E.D. Weil, M. Lewin, Polym. Int. 48 (1999) 532-557.

[24] C. Isbasar, J. Hacaloglu, J. Anal. Appl. Pyrolysis 98 (2012) 221-230.

[25] P. Gijsman, R. Steenbakkers, C. Furst, J. Kersjes, Polym. Degrad. Stab. 78 (2002) 219-224.

[26] Y. Nagasawa, M. Hotta, K. Ozawa, J. Anal. Appl. Pyrolysis 33 (1995) 253267.

[27] Y. Nagasawa, M. Yamamoto, Y. Ozawa, Thermochim. Acta 267 (1995) 223-230.
[28] A. Casu, G. Camino, M. De Giorgi, D. Flath, V. Morone, R. Zenoni, Polym. Degrad. Stab. 58 (1997) 297-302.

[29] E.D. Weil, S. Levchik, J. Fire Sci. 22 (2004) 251-264.

[30] P. Girods, A. Dufour, Y. Rogaume, C. Rogaume, A. Zoulalian, J. Anal. Appl. Pyrolysis 81 (2008) 113-120.

[31] R. Sonnier, L. Ferry, C. Longuet, F. Laoutid, B. Friederich, A. Laachachi, J.-M. Lopez-Cuesta, Polym. Adv. Technol. 22 (2011) 1091-1099.

[32] R.E. Lyon, M.T. Takemori, N. Safronava, S.I. Stoliarov, R.N. Walters, Polymer 50 (2009) 2608-2617.

[33] H. Lu, C.A. Wilkie, Polym. Adv. Technol. 22 (2011) 14-21.

[34] H. Lu, C.A. Wilkie, Polym. Degrad. Stab. 95 (2010) 564-571.

[35] J.M. Cogen, T.S. Lin, R.E. Lyon, Fire Mater. 33 (2009) 33-50.

[36] R.E. Lyon, R.N. Walters, S.I. Stoliarov, Polym. Eng. Sci. 47 (2007) 1501-1510.

[37] R. Nakamura, A.N. Netravali, A.B. Morgan, M.R. Nyden, J.W. Gilman, Fire Mater. 37 (2013) 1-90.

[38] T.D. Hapuarachchi, E. Bilotti, C.T. Reynolds, T. Peijs, Fire Mater. 35 (2011) 157169.

[39] X. Chen, C. Jiao, J. Zhang, Polym. Eng. Sci. 52 (2012) 414-419.

[40] C. Gerard, G. Fontaine, S. Bourbigot, Polym. Adv. Technol. 22 (2011) 10851090.

[41] R. Sonnier, A. Viretto, A. Taguet, J.-M. Lopez-Cuesta, J. Appl. Polym. Sci. 125 2012) 3148-3158

[42] A.B. Morgan, M. Galaska, Polym. Adv. Technol. 19 (2008) 530-546.

[43] R. Sonnier, H. Vahabi, L. Ferry, J.-M. Lopez-Cuesta, in: C. Wilkie (Ed.), Fire and Polymers VI: New Advances in Flame Retardant Chemistry and Science, ACS Books, 2012.

[44] M. Lewin, A. Basch, in: M. Lewin, S.M. Atlas, E.M. Pearce (Eds.), Structure, Pyrolysis, and Flammability of Cellulose Structure, vol. 2, Plenum Press, New York, 1978, pp. 1-40.

[45] S. Soares, G. Caminot, S. Levchik, Polym. Degrad. Stab. 49 (1995) 275-283.

[46] G. Dorez, A. Taguet, L. Ferry, J.-M. Lopez-Cuesta, Polym. Degrad. Stab. 98 (2013) $87-95$. 